\title{
Pengaruh Model Brain Based Learning (BBL) Terhadap Hasil Belajar Siswa Kelas XI pada Materi Laju Reaksi
}

\author{
The Influence of Brain Based Learning (BBL) Model toward Learning Outcomes of \\ Students Grade XI on Reaction Rate Materials
}

\author{
H. H. Basri*, S. M. Sabang dan M. R. Jura \\ Prodi Pendidikan Kimia, FKIP Universitas Tadulako \\ *e-mail: hikmahhasanbasri1506@gmail.com
}

\begin{tabular}{l}
\hline Article Info \\
\hline Article History: \\
Received: 06 Mei 2021 \\
Accepted: 20 Mei 2021 \\
Published: 31 Mei 2021 \\
Keywords: \\
Brain Based Learning \\
Model \\
Learning Outcomes \\
Reaction Rate
\end{tabular}

\section{PENDAHULUAN}

Perkembangan ilmu pengetahuan, teknologi, dan seni telah berlangsung secara terus menerus seiring dengan perkembangan zaman yang tidak pernah berhenti, dan akan selalu memunculkan hal-hal baru dalam kehidupan. Sehingga perkembangan didunia pendidikan juga menunjukkan kemajuan yang bertahap [1].

Peraturan Pemerintah No. 20 Tahun 2003 Tentang Sistem Pendidikan Nasional [2], menjelaskan bahwa pendidikan adalah usaha sadar dan terencana untuk menwujudkan suasana belajar dan proses pembelajaran agar peserta didik secara aktif mengembangkan potensi dirinya. Pendidikan merupakan sarana yang sangat penting bagi kelangsungan hidup manusia, hal ini disebabkan karena pendidikan adalah sektor yang dapat menciptakan kecerdasan manusia dalam melangsungkan kehidupannya [3].

Salah satu aspek yang sangat penting dalam pembangungan negara sebagai sarana untuk meningkatkan kualitas sumber daya manusia (SDM) yaitu dengan pendidikan. Melalui pendidikan dapat dibentuk manusia yang mampu membangun dirinya sendiri dan negara, maka dari perlu dilakukannya peningkatan pada mutu pendidikan [4].
Kemajuan suatu bangsa tidak terlepas dari faktor pendidikan, karena pendidikan mempunyai peranan penting dalam usaha meningkatkan sumber daya manusia yang merupakan unsur terpenting dalam mewujudkan dan menyempurnakan mutu pendidikan dengan meningkatkan kualitas proses belajar mengajar. Oleh karena itu keberhasilan pendidikan banyak tertumpuh kepada bagaimana proses mengajar yang dilakukan oleh guru [5].

Pendidikan di Indonesia masih memiliki permasalahan pada persoalan mutu pendidikan, karena rendahnya mutu pendidikan dapat berimplikasi pada rendahnya sumber daya manusia (SDM). Departemen Pendidikan Nasional telah melakukan berbagai upayanya dalam mengatasi permasalahan tersebut. Upaya yang dilakukan yaitu yang mencakup semua komponen pendidikan seperti proses pembelajaran, peningkatan kualitas guru, pengadaan buku pelajaran dan sarana maupun prasarana lainnya serta penyempurnaan sistem pendidikan. Proses pembelajaran dikelas tidak lepas dari aktivitas siswa yang diharapkan dapat meningkatkan pengalaman belajar sehingga proses pembelajaran menjadi lebih bermakna bagi peserta didik [6].

Proses pembelajaran sains dalam mempelajari IPA akan berjalan sesuai dengan kaidah yang benar manakala subjek yang melaksanakan memiliki sikap ilmiah yang memadai. 
Kecenderungan seseorang untuk berperilaku dan mengambil tindakan pemikiran ilmiah yang sesuai dengan metode ilmiah inilah yang disebut dengan sikap ilmiah [7]. Mata pelarajaran kimia merupakan bagian dari dari pelajaran sains, yang memfokuskan dalam mengkaji struktur, sifat dan perubahan materi memiliki karakteristik permasalahan yang berbeda dengan mata pelajaran lainnya. Oleh karena itu, diperlukan strategi tertentu dalam mengatasinya [8].

Penerapan model pembelajaran yang bervariasi bertujuan untuk menunjang kegiatan pembelajaran itu sendiri serta membantu guru dalam proses pembelajaran agar lebih menarik, efektif, dan efisien. Salah satu model pembelajaran yang menarik, efektif dan efisien yang dapat digunakan dalam proses pembelajaran adalah model brain based learning. Model brain based learning merupakan sebuah konsep pembelajaran dengan berorientasi pada pemberdayaan potensi otak siswa. Model pembelajaran ini dapat menciptakan lingkungan belajar yang menantang kemampuan berpikir siswa, menciptakan lingkungan pembelajaran yang menyenangkan, dan menciptakan situasi pembelajaran yang aktif dan bermakna bagi siswa [9].

Dalam pembelajaran IPA fungsi otak tidak seharusnya ditekankan hanya pada penghapalan materi, namun juga siswa perlu diberikan kesempatan pada kegiatan yang memerlukan keterampilan motorik siswa, seperti pada kegiatan mengamati objek, melakukan percobaan, berdiskusi dan sebagainya, sehingga mampu membuat siswa menjadi aktif dan menyelaraskan fungsi otaknya dengan baik [10].

Pemahaman tentang bagaimana cara kerja otak dalam proses pembelajaran dapat memudahkan dalam mendesain model pembelajaran. Proses pembelajaran merupakan proses perubahan perilaku sebagai bentuk dari hasil belajar [11]. Cara kerja otak memiliki dampak yang signifikan pada jenis kegiatan belajar apa yang paling efektif. Tiga elemen interaktif yang sangat penting dalam proses ini yaitu 1) Guru harus membenamkan peserta didik dalam pengalaman yang kompleks dan interaktif yang kaya dan nyata. Salah satu contoh yang sangat baik adalah membenamkan siswa dalam budaya asing untuk mengaja rmereka bahasa kedua. Pendidik harus mengambil keuntungan dari kemampuan otak untuk proses paralel. 2) Siswa harus memiliki tantangan yang bermakna secara pribadi. Tantangan seperti itu dapat merangsang pikiran siswa ke keadaan kewaspadaan yang dinginkan. 3) Agar siswa mendapatkan wawasan tentang masalah, harus ada analisis intensif tentang berbagai cara untuk mendekatinya, dan tentang belajar secara umum. Inilah yang dikenal sebagai pemrosesan pengalaman secara aktif [12].

Sudjana [13] mendefinisikan hasil belajar siswa sebagai pola perubahan tingkah laku. Sedangkan dalam arti luasnya mencakup bidang kognitif, afektif dan psikomotorik. Faktor yang mempengaruhi rendahnya hasil belajar siswa adalah proses pembelajaran yang merupakan inti dari proses pendidikan formal di sekolah yang di dalamnya terdapat interaksi antara guru, materi, dan siswa. Proses pembelajaran tentunya akan melibatkan sarana dan prasarana seperti; metode, model pembelajaran, media, dan penataan lingkungan tempat belajar sehingga tercipta situasi belajar mengajar yang memungkinkan untuk mencapai tujuan pembelajaran [14].
Berdasarkan hasil wawancara dengan guru mata pelarajan kimia di SMA Negeri 7 Palu di peroleh informasi bahwa pembelajaran yang sering dilakukan guru adalah pembelajaran teacher-centered. Guru menjadi sumber dan pemberi informasi utama dalam proses pembelajaran. Siswa cenderung menjadi pasif dalam menerima dan mengikuti penjelasan guru, dimana siswa hanya sebagai pendengar dan pencatat dalam proses pembelajaran. Hal tersebut menyebabkan siswa kurang termotivasi untuk belajar secara mandiri dan sangat bergantung pada pengetahuan yang langsung diberikan oleh guru sehingga hasil belajar yang diperoleh masih memiliki nilai standar.

Berdasarkan uraian yang telah dikemukakan diatas, maka penulis bertujuan untuk mengetahui pengaruh dari model Brain Based Learning terhadap hasil belajar siswa kelas XI pada materi laju reaksi di SMA Negeri 7 Palu.

\section{METODE}

Jenis penelitian yang digunakan adalah penelitian eksperimen semu (Quasy Esperiment). Kegiatan penelitian ini dilaksanakan di SMA Negeri 7 Palu. Sampel yang digunakan dalam penelitian ini adalah siswa kelas XI MIA 2 yang berjumlah 25 orang sebagai kelas eksperimen dan siswa kelas XI MIA 5 yang berjumlah 23 orang sebagai kelas kontrol. Teknik pengambilan sampel yaitu dengan cara purposive sampling (sampel pertimbangan).

Instrumen yang digunakan dalam penelitian ini yaitu instrumen tes hasil belajar berupa soal pilihan ganda yang digunakan untuk mengukur hasil belajar siswa kelas XI di SMA Negeri 7 Palu dan lembar observasi aktivitas guru dan siswa untuk mengamati pelaksanaan proses kegiatan pembelajaran baik di kelas eksperimen maupun kelas kontrol.

Teknik analisis data dari penelitian ini yaitu analisis instrumen tes yang dilakukan kepada siswa kelas XII MIA 4 di SMA Negeri 7 Palu yang kemudian hasilnya dianalisis dengan menggunakan aplikasi AnatestV4 untuk mengetahui validitas, reliabilitas, tingkat kesukaran, dan daya pembeda (Arif, 2014). Analisis pengujian hipotesis menggunakan uji statistik non parametrik uji Mann Whitney (Uji-u) [15].

\section{HASIL DAN PEMBAHASAN}

Hasil analisis data yang diperoleh selama proses pembelajaran berlangsung berupa lembar observasi guru dan siswa yang disajikan dalam bentuk Tabel 1 dan Tabel 2.

Tabel 1. Hasil observasi aktivitas guru kelas eksperimen dan kelas kontrol

\begin{tabular}{ccc}
\hline \multirow{2}{*}{ Pertemuan } & \multicolumn{2}{c}{ Persentase (\%) } \\
\cline { 2 - 3 } & $\begin{array}{c}\text { Kelas } \\
\text { Esperimen }\end{array}$ & Kelas Kontrol \\
\hline 1 & 82,35 & 81,25 \\
2 & 80,88 & 82,69 \\
3 & 80,88 & 82,69 \\
Rerata Skor & 82,03 & 82,21 \\
\hline
\end{tabular}

Tabel 2. Hasil observasi aktivitas siswa kelas eksperimen dan kelas kontrol

Pertemuan $\quad$ Persentase $(\%)$ 


\begin{tabular}{ccc}
\cline { 2 - 3 } & $\begin{array}{c}\text { Kelas } \\
\text { Esperimen }\end{array}$ & Kelas Kontrol \\
\hline 1 & 77,94 & 75 \\
2 & 83,82 & 78,84 \\
3 & 83,82 & 78,84 \\
Rerata Skor & 81,86 & 77,56 \\
\hline
\end{tabular}

Data Tabel 1 menunjukan bahwa dalam proses pembelajaran observasi aktivitas guru berada dalam kategori baik dan Tabel 2 menunjukan bahwa selama proses pembelajaran berlangsung observasi aktivitas siswa berada dalam kategori baik, tetapi persentase kelas eksperimen lebih tinggi dibanding kelas kontrol.

Hasil belajar siswa diperoleh melalui pemberian tes akhir setelah semua proses pembelajaran selesai dilaksanakan (Posttest). Tes akhir dilakukan dengan tujuan untuk mengetahui sejauh mana pengaruh model pembelajaran yang digunakan pada kedua kelas, dengan model brain based learning pada kelas eksperimen dan metode ceramah dan diskusi pada kelas kontrol terhadap materi laju reaksi. Data hasil belajar siswa disajikan dalam bentuk Tabel 3 .

Tabel 3. Data hasil belajar siswa kelas eksperimen dan kelas kontrol

\begin{tabular}{ccc}
\hline \multirow{2}{*}{ Uraian } & \multicolumn{2}{c}{ TesAkhir } \\
\cline { 2 - 3 } & $\begin{array}{c}\text { Kelas } \\
\text { Esperimen }\end{array}$ & KelasKontrol \\
\hline Sampel & 25 & 23 \\
Nilai Tertinggi & 100 & 79 \\
NilaiTerendah & 63 & 16 \\
Skor rata-rata & 89,16 & 56,47 \\
\hline
\end{tabular}

Berdasarkan Tabel 3 dapat dilihat bahwa nilai rata-rata siswa kelas eksperimen dengan menggunakan model brain based learning lebih tinggi dibanding kelas kontrol yang menggunakan metode ceramah dan diskusi.

Data hasil belajar tersebut kemudian dianalisis dengan menggunakan statistik inferensial. Analisis statistik sendiri dilakukan dengan tujuan untuk melihat konsistensi dari model pembelajaran yang digunakan.

Hasil pengujian normalitas dilakukan dengan menggunakan uji chi-quadrat. Hasil perhitungan diperoleh data pada kelas eksperimen $X_{\text {hitung }}^{2}=14,73$ dengan $X_{\text {tabel }}^{2}=$ 5,99 , dan pada kelas kontrol $X_{\text {hitung }}^{2}=10,25$ dengan $X_{\text {tabel }}^{2}=$ 5,99 . Berdasarkan pada kriteria pengambilan keputusan yaitu $X_{\text {hitung }}^{2} \leq X_{\text {tabel }}^{2}$ maka dapat dilihat bahwa data pengujian normalitas pada kedua kelas berdistribusi tidak normal, karena $X_{\text {hitung }}^{2}$ pada kedua kelas lebih besar dari $X_{\text {tabel }}^{2}$. Sehingga pengujian hipotesisnya menggunakan uji statistik non parametrik.

Pengujian hipotesis pada penelitian ini menggunakan uji non parametrik yaitu uji Mann Whitney (Uji-U) (Sugiyono, 2015). Uji Mann Whitney merupakan uji dua sampel pada uji statistik non parametrik dimana tujuannya sama dengan uji $\mathrm{t}$ pada statistik parametrik [16]. Berdasarkan hasil perhitungan diperoleh $\mathrm{Z}_{\text {hitung }}>\mathrm{Z}_{\text {tabel }}$ yaitu 4,38 $>1,96$ jelas berada pada daerah penerimaan $\mathrm{H} 1$ hasil tersebut telah menunjukkan bahwa hasil belajar siswa kelas eksperimen $(\mu 1)$ tidak sama dengan hasil belajar siswa kelas kontrol $(\mu 2)$ pada materi laju reaksi. Dengan hasil tersebut maka dapat disimpulkan bahwa hipotesis yang diajukan telah menerima $\mathrm{H} 1$ dan menolak $\mathrm{H} 0$, yaitu ada pengaruh model brain based learning terhadap hasil belajar siswa pada materi laju reaksi di kelas XI MIA di SMA Negeri 7 Palu.

Hasil tersebut didukung oleh data observasi yang diperoleh menggunakan penilaian lembar observasi aktivitas guru dan siswa, dimana lembar obsevasi tersebut merupakan jalannya proses pembelajaran yang terjadi didalam kelas baik pada kelas eksperimen maupun kelas kontrol. Dapat dilihat pada persentase rata-rata observasi aktivitas pada kedua kelas. Keduanya berada pada kategori baik, tetapi persentase kelas eksperimen dengan menggunakan model brain based learning lebih tinggi dibanding kelas kontrol yang hanya menggunakan metode ceramah dan diskusi. Nilai rata-rata persentase kelas eksperimen yaitu 81,86 dan kelas kontrol yaitu 77,56.

Pembelajaran di kelas eksperimen menggunakan desain pembelajaran berbasis pada kemampuan otak (brain based learning). Brain based learning menuntut siswa untuk aktif dalam pembelajaran selama proses pembelajaran berlangsung untuk menemukan pengetahuan tentang topik yang sedang dipelajari [17].

Proses yang dimaksud adalah tahapan dan kondisi yang memudahkan otak untuk menangkap informasi dengan baik secara alamiah. Hal ini sejalan dengan penelitian yang dilakukan oleh Witariani [18] yang mengatakan bahwa model brain based learning merupakan model pembelajaran yang diselaraskan dengan cara kerja otak yang didesain secara alamiah untuk belajar melalui situasi pembelajaran yang menantang, menyenangkan, serta aktif dan bermakna bagi siswa. Tahapan pembelajaran yang dilaksanakan dengan menghubungkan peristiwa dalam kehidupan sehari-hari yang berkaitan dengan materi laju reaksi, serta komunikasi yang terjalin dengan baik antara guru dengan siswa maupun siswa dengan siswa lainnya yang dapat menciptakan suasana belajar yang kondusif bagi siswa dalam menangkap informasi dengan baik.

Pada model brain based learning peserta didik dituntut agar lebih aktif dalam pembelajaran karena siswa diberikan kendali untuk mengelola pembelajarannya secara mandiri dimana siswa dituntut untuk mampu mengidentifikasi berbagai masalah. Selain itu model brain based learning merupakan model pembelajaran yang berpusat pada siswa [6].

Metode diskusi juga digunakan dalam model brain based learning. Tujuan dari penggunaan metode diskusi ini adalah agar siswa lebih mampu bekerja sama dengan siswa lain dalam kelompoknya, juga mampu mengungkapkan ide serta gagasan mereka dengan baik, dapat menjadi lebih aktif serta bisa meningkatkan keberanian dan rasa percaya diri dalam hal positif. Pengajaran yang efektif menghendaki guru memfasilitasi siswa belajar dengan metode diskusi agar siswa bisa bekerja sama dan bisa belajar aktif untuk melatih keberanian dan kepercayaan diri siswa [19].

Pembelajaran dengan model brainbased learning memberikan kesempatan kepada siswa agar mendapatkan pengalaman melalui aktivitas fisik dan melatih kemampuan berkomunikasi. Keterlibatan siswa secara fisik dipadukan dengan intelektual siswa dalam pelajaran melatih siswa untuk mampu menyelesaikan masalah-masalah yang ditemuinya 
dalam kehidupan sehari-hari dan menjadikan pembelajaran lebih bermakna [20].

Pembelajaran di kelas kontrol dilakukan dengan metode ceramah dan diskusi berbantuan buku-buku mata pelajaran kimia serta literatur lainnya. Dalam pelaksanaan proses pembelajaran di kelas kontrol, guru menyampaikan materi serta memberikan latihan soal, melakukan pembahasan latihan soal dan juga tanya jawab menganai materi yang sebelumnya telah dipelajari. [21] mengatakan bahwa kegiatan pembelajaran yang dilakukan melalui informasi dari guru ke siswa atau teacher-centered yang diisi dengan tanya jawab dan pemberian tugas. Pembelajaran yang bersifat seperti ini membuat siswa menjadi tidak bebas dalam mengeluarkan idenya secara kreatif dan siswa pun cenderung menjadi lebih pasif.

Perbedaan antara kedua model pembelajaran ini disebabkan oleh beberapa hal diantaranya yaitu, hal-hal yang ditunjukan pada proses pembelajaran di kelas eksperimen tidak nampak di kelas kontrol yang menggunakan pembelajaran konvensional dengan metode ceramah dan eksperimen. Dalam pengajaran ini, guru mengkomunikasikan pengetahuannya kepada siswa dengan teknik ceramah. Kegiatan pembelajaran dimulai dari uraian untuk memperjelas bahan ajar disertai dengan contoh-contoh, siswa mencatat, bertanya, kemudian guru menjawab, dan diakhiri dengan latihan sebagai umpan balik. Menggunakan metode tersebut, keaktifan siswa sangat kurang karena membuat siswa tidak bebas mengeluarkan idenya secara kreatif dan siswa cenderung menjadi pasif. Hal ini menyebabkan proses belajar dan konsentrasi siswa kurang maksimal sehingga pada saat ditanya kembali mengenai materi yang telah diajarkan masih adas iswa yang masih bingung karena tidak terlibat aktif dalam proses pembelajaran.

Rendahnya nilai rata-rata hasil belajar belajar siswa pada kelas kontrol disebabkan karena dalam proses pembelajaran ini interaksi yang terjadi antara siswa dan pengajar masih sangat kurang dan juga siswa tidak terdorong untuk mencari tetapi hanya menerima apa yang diberikan dalam proses pembelajaran.

Berdasarkan pada pertimbangan dan semua data yang telah dijabarkan makadapat diketahui bahwa model Brain Based Learning memberikan pengaruh yang baik terhadap hasil belajar siswa. Hasil penelitian ini diperkuat dengan hasil penelitian dari Purnama [22] yang menyatakan bahwa pembelajaran dengan model brain based learning menggunakan metode mind mapping berpengaruh positif terhadap hasil belajar siswa kelas X MIA pada materi ikatan kimia.

\section{KESIMPULAN}

Berdasarkan penelitian yang telah dilakukan mengenai pengaruh model brain based learning terhadap hasil belajar siswa kelas XI pada materi laju reaksi di SMA Negeri 7 Palu, makadapat disimpulkan bahwa model brain based learning berpengaruh baik terhadap hasil belajar siswa kelas XI pada materi laju reaksi di SMA Negeri 7 Palu. Hal ini terlihat dari skor rata-rata hasil belajar siswa masing-masing kelas, yaitu nilai rata-rata kelas eksperimen yang menerapkan model brain based learning sebesar 89,16 dannilai rata-rata kelas kontrol yang menerapkan model pembelajaran dengan metode ceramah dan diskusi sebesar 59,47.

\section{UCAPAN TERIMA KASIH}

Penulis mengucapkan banyak terimakasih kepada Sitti Hajar, guru mata pelajaran kimia kelas XI SMA Negeri 7 Palu, adik-adik kelas XI MIA 2 dan adik-adik kelas XI MIA 5 SMA Negeri 7 Palu yang turut membantu penulis sehingga penelitian ini berjalan dengan baik dan lancar.

\section{REFFERENSI}

[1] L. Badriah, \& D. Ramdani, "Model brain based learning (bbl) untuk meningkatkan hasil belajar siswa sekolah dasar pada pokok bahasan system indra. Jurnal Penelitian Pendidikan dan Pembelajaran, 3(1), 2018, pp. 303-309.

[2] RI, "Undang-Undang Nomor 20 Tahun 2003 Tentang Sistem Pendidikan Nasional," Bandung: Citra Umbara, 2003.

[3] D. Kurniawati, M. Masykuri, \& S. Saputro, "Penerapan model pembelajaran inkuiri terbimbing dilengkapi lks untuk meningkatkan keterampilan proses sains dan prestasi belajar pada materi pokok hukum dasar kimia siswa kelas x MIA 4 SMANegeri 1 Karanganyar tahun pelajaran 2014/2015," Jurnal Pendidikan Kimia, 5(1), 2016, pp. 88-95.

[4] T. Utomo, D. Wahyuni, \& S. Hariyadi, "Pengaruh model pembelajaran berbasis masalah (problem based learning) terhadap pemahaman konsep dan kemampuan berpikir kreatif siswa (siswa kelas viii semester gasal SMPN 1 Sumbermalang kabupaten Situbondo tahun ajaran 2012/2013)," Jurnal Edukasi Universitas Jember, 1(1), 2014, pp. 5-9.

[5] Masykur, "Meningkatkan hasil belajar matematika melalui model pembelajaran kooperatiftipe tutor sebaya," Jurnal Matematika dan Pendidikan Matematika, 9(2), 2018, pp. 8-15.

[6] I. G. A. Mustiada, A. A. G. Agung, \& N. N. M. Antari, "Pengaruh model bbl (brain based learning) bermuatan karakter terhadap hasil belajar IPA. Jurnal Mimbar PGSD Universitas Pendidikan Ganesha Jurusan PGSD, 2(1), 2014, pp. 1-10.

[7] Sodikin, "Penerapan pembelajaran berbasis masalah melalui metode eksperimen dan demonstrasi ditinjau dari kemampuan menggunakan alat ukur dan sikap ilmiah siswa," Jurnal Ilmiah Pendidikan Fisika, 04(2), 2015, pp. 257-269.

[8] I. W. Soma, "Meningkatkan aktivitas dan hasil belajar siswa melalui penerapan strategi siklus ACE pada pembelajaran kimia," Jurnal Sains dan Teknology, 11(3), 2012, pp. 106-115. 
[9] R. Sayoga, Ramlah, \& M. R. Utami, "Pengaruh model brain based learning (BBL) terhadap kemampuan berpikir kritis matematis siswa SMA," Seminar Nasional Matematika dan Pendidikan Matematika (ISBN: 978602-60550-1-9), 2017, pp. 349-357.

[10] N. W. Ardiani, D. B. Kt. Ngr. S. Putra, \& I. B. Gd. Abadi, "Model brain based learning (bbl) bernuansa lingkungan sekitar berpengaruh terhadap hasil belajar IPA siswa kelasV SD," Jurnal Mimbar PGSD Universitas Pendidikan Ganesha Jurusan PGSD, 2(1), 2014, pp. 1-10.

[11]B. S. Handayani, \& A. D. Corebim, "Model brain based learning (bbl) and whole brainteaching (wbt) in learning," International Jurnal of Science and Applied Science: Conference Series, 1(2), 2017, pp. 153-161.

[12] V. G. Rangrej, "Teaching methods - brain based learning," Electronic International Interdisciplinary Research Journal (EIIRJ), \{ Bi-Monthly \}, 1(2), 2012, 94100

[13] N. Sudjana, "Penilaian hasil proses belajar mengajar," Bandung: Remaja Rosda karya, 2009.

[14] M. Arif, "Penerapan aplikasi anates bentuk soal pilihan ganda,” Jurnal Ilmiah Edutic, 1(1), 2014, pp. 1-9.

[15]I. S. Fajriati, Safei, \& Saprin. "Pengaruh penerapan metode pembelajaran brain based learning berbantuan brain gym terhadap hasil belajar peserta didik," Jurnal Biotek, 5(1), 2017, pp. 1-10.

[16] Sugiyono, "Metode penelitian pendidikan pendekatan kuantitatif, kualitatif, dan ROD," Bandung: Alfabeta, 2015 .

[17] S. Suranto and D. Apriliani, "Analisis perbedaan mental wirausaha mahasiswa dengan non parametrik," Jurnal Ilmiah Teknik Industri, 10(1), 2011, pp. 35-41.

[18] R. L. Sadikin \& G. M. Muhammad, "Peningkatan kemampuan berpikirkritis matematis siswa SMA dengan model brain based learning," Triple S. Journals on Mathematics Education, 1(1), 2018, pp. 15-28.

[19]P. E. Witariani, N. Dantes, dan I. N. Tika, "Pengaruh model brain based learning berbantuan media visual terhadap hasil belajar IPA ditinjau dari sikap ilmiah siswa kelas V SD Gugus 1 Kecamatan Banjar tahun pelajaran 2013/2014," e-Journal Program Pascasarjana Universitas Pendidikan Ganesh, 4(1), 2014, pp. 1-12.

[20] Irma, "Pengaruh Model Brain Based Learning Terhadap Keterampilan Berpikir Kritis dan Hasil Belajar Siswa SMA Negeri 9 Palu Pada Materi Larutan Asam Basa," Tesis. Palu: Universitas Tadulako, 2015.

[21] R. Saparina, S. Santosa, \& Maridi, "Pengaruh model brain based learning (bbl) terhadap hasil belajar biologi siswa kelas $\mathrm{x}$ SMA Negeri Colomadu tahunpe lajaran 2012/2013," Jurnal BIO-PEDAGOGI, 4(1), 2015, pp. 5965

[22] N. S. Pratiwi, I. A. S. Asri, \& S. Putra, "Pengaruh model brain-based-learningberbantuan media diorama terhadap hasil belajar IPS siswa kelasV SD Gugus VII Sukawati tahun ajaran 2013/2014," Jurnal Mimbar PGSD, 2(1), 2014, pp. 1-10.

[23] R. Purnama, "Pengaruh Mind Mapping Melalui Brain Based Learning Terhadap Hasil Belajar Siswa Pada Materi Ikatan Kimia Di Kelas X MIA SMA Negeri 1 Marawola," Skripsi. Palu. Universitas Tadulako, 2015. 